\title{
Spirulina platensis Effects on the Levels of Total Cholesterol, HDL and Triacylglycerols in Rabbits Fed with a Hypercholesterolemic Diet
}

\author{
Luciane Maria Colla ${ }^{1}$, Ana Luiza Muccillo-Baisch ${ }^{2}$ and Jorge Alberto Vieira Costa ${ }^{3 *}$ \\ ${ }^{1}$ Laboratório de Fermentações; Faculdade de Engenharia e Arquitetura, Engenharia de Alimentos; Universidade \\ de Passo Fundo; C. P.: 611; 99001-970; Passo Fundo - RS - Brasil. ${ }^{2}$ Departamento de Ciências Fisiológicas; \\ ${ }^{3}$ Laboratório de Engenharia Bioquímica; Departamento de Química; Fundação Universidade Federal do Rio \\ Grande - FURG; C. P.: 474; dqmjorge@furg.br; 96201-900; Rio Grande - RS - Brasil
}

\begin{abstract}
In this work, hypercholesterolemia was induced in rabbits by feeding them a high cholesterol diet (CD, $350 \mathrm{mg} / \mathrm{d})$ and the effects of supplementing this diet with $0.5 \mathrm{~g} / \mathrm{d}$ Spirulina platensis was evaluated by measuring the levels of serum total-cholesterol (TC), triacylglycerols (TAG) and high-density lipoprotein (HDL-cholesterol) at the start of the experiment and after $30 \mathrm{~d}$ and $60 \mathrm{~d}$. It was found that the levels of serum cholesterol decreased from 1,054 \pm 101 $\mathrm{mg} . d L^{-1}$ in the rabbits fed a CD without $\underline{S \text {. platensis }}$ to $516 \pm 163 \mathrm{mg} . \mathrm{dL}^{-1}$ to those fed with a high cholesterol diet

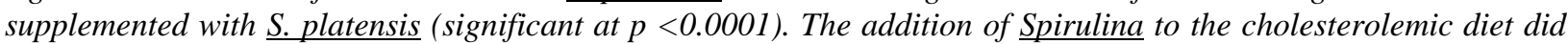
not cause significative decrease on the levels of triacylglycerols in the animals. The levels of serum high-density lipoprotein (HDL-cholesterol) was $73 \pm 31 \mathrm{mg} . d L^{-1}$ for rabbits fed a CD without $\underline{S}$. platensis as compared to

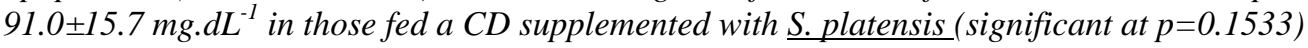

Key words: Spirulina platensis, cholesterol, rabbits

\section{INTRODUCTION}

It is known that natural antioxidants can inhibit the hypercholesterolemia, and their effect in many cases has been proved. One of the most known cases is the "French paradox", an apparent compatibility of a diet with high fat ingestion with a low incidence of atherosclerosis, due to the consumption of red wine, which presents considerable amounts of antocyanins, natural pigments with phenolic structure (Renaud and Lorgeril, 1992; Amaral et al., 1995). Considering the high cost of the medicaments, alternative treatments for the control of the hypercholesterolemia have been used in the popular medicine as the ingestion of capsules of poly-unsaturated fatty acids or fruits and vegetables extracts that present substances with antioxidant potential, as the eggplant and the mate (Gugliucci, 1996; Perugini et al., 2000; Schinella et al., 2000). Among the substances with antioxidant potential, are the ascorbic acid and the phenolic compounds (Gardner et al., 2000). The cyanobacterium Spirulina is cultivated and commercialized worldwide due to its nutritional characteristics including high concentrations of protein $(\sim 65 \%)$, vitamins and mineral salts (Henrikson, 1994; Belay et al., 1993).

\footnotetext{
* Author for correspondence
} 
Preparations of Spirulina are also used for their therapeutic properties in the treatment of many diseases, including hypercholesterolemia and atherosclerosis (Nakaya et al., 1988; Ramamoorthy and Premakumari, 1996), as well as to reduce body weight in obese humans (Becker et al., 1986). The Spirulina components which are responsible for these therapeutic properties are thought to be compounds with antioxidant abilities such as polyunsaturated fatty acids, phycocyanin (Estrada et al., 2001; Bhat and Madyastha, 2001; Reddy et al., 2003, Nagaoka et al., 2005) and phenolics (Miranda et al., 1998). Of the compounds present in Spirulina, gammalinolenic acid (C18:3, $\omega 6$, GLA) and phycocyanin are those which have received most attention from researchers.

The aim of this work was to study the opposite effects of cholesterol and Spirulina platensis diets on the levels of cholesterol, triacylglycerols and HDL-cholesterol in rabbits.

\section{MATERIAL AND METHODS}

\section{Animals}

Fifteen males New Zealard white rabbits, weighing $3496 \pm 336 \mathrm{~g}$, 8 weeks old, were included in this study. Animals were housed individually and water was provided at libitum. After adaptation, rabbits were equally divided in five groups. All animals were fed daily with $100 \mathrm{~g}$ of feed, and feed was specific to each group.

\section{Diets}

The first group of animals (SDG-standard diet group) was fed with a standard feed-SD (Nuvital Nutrients, Brazil). The second group (CDGcholesterol diet group) was fed with a cholesterol added diet (CD-cholesterol diet), containing $3.5 \mathrm{~g}$ of cholesterol per $1,000 \mathrm{~g}$ of SD $(0.35 \%)$. The cholesterol was dissolved in $100 \mathrm{~g}$ of lard previously heated. The percents of cholesterol used in this kind of studies has been $0.35 \%$ (Amaral et al., 1995), 0.5\% and 1\% (Keaney et al., 1993; Mahfouz et al., 1997, Silva et al., 1997). The third group (CSDG-Cholesterol-Spirulina diet group) was fed with a Spirulina added diet (CSDcholesterol-Spirulina diet) prepared with the addition of $5.0 \mathrm{~g}$ of $S$. platensis biomass (Delaware, Brazil) per 1,000 g of the cholesterol added diet $(\mathrm{CD})$, and the animals were provided
$0.5 \mathrm{~g}$ of Spirulina/d. The fourth group (CSDG30) was fed with the $C D$ in the first month and with the CSD in the second month of treatment. The lard was used to aggregate homogeneously the powder of cholesterol and the Spirulina biomass to the feed. However, as the lard is constituted by saturated fat, it was necessary to evaluate the influence of this one on the animals' lipoprotein levels. In this way, a fifth group of animals (FDGfat diet group) was fed with a fat diet (FD), prepared by the addition of $100 \mathrm{~g}$ of lard in 1,000 $\mathrm{g}$ of standard feed.

\section{Determinations of Feed Composition}

Determinations of humidity, proteins, lipids and ashes were accomplished following the methodology of A.O.A.C (1995) to determine the final composition of the diets.

\section{Measurement of Serum Lipids Levels}

Approximately $4 \mathrm{~mL}$ of blood was drawn from the central ear artery of the rabbits at $0 \mathrm{~d}, 30 \mathrm{~d}$ and 60 $\mathrm{d}$ of treatment. Serum total cholesterol, triacylglycerols and high-density-lipoprotein (HDL) were assayed using commercial enzyme kits (Wiener Lab, Argentina; Lab Test, Brazil) on Vitalab Selectra 2 equipment.

\section{Statistical Analysis}

Data are expressed as means \pm standard deviations of the mean. Statistical differences among the groups were determined using ANOVA and Tukey test with $\mathrm{p}<0.05$ considered statistically significant.

\section{RESULTS AND DISCUSSIONS}

\section{Diets and Animals}

The composition analysis of the diets, presented in Table 1 demonstrated some variations on the percentiles of humidity, ashes, proteins and lipids. The standard feed (SD) presented the lowest lipid content $(5.19 \%)$ when compared with the others diets ( 13.80\%), which could be explained because this diet was not added of lard. The cholesterol added in CD (cholesterol-diet) and CSD (cholesterol-Spirulina-diet) $\left(350 \mathrm{mg} .100 \mathrm{~g}^{-1}\right)$ caused no differences on lipids percentiles, even though it could cause significant differences on the serum lipids levels. 
Table 2 presents the animals' weights in the beggining and at the end of the treatments. No significative differences were observed $(\mathrm{p}=0.05)$.

\section{Serum Lipids Levels}

Table 3 presents the values of total-cholesterol (TC), triacylglycerols (TAG) and HDL-cholesterol in the rabbits on 0,30 and $60 \mathrm{~d}$ of treatment. Results of ANOVA demonstrated that the interaction of treatment time $(0,30$ and $60 \mathrm{~d})$ and diets groups of rabbits (SDG, CDG, CSDG, CSDG30 and FDG) had significant influence in levels of total cholesterol $(\mathrm{p}<0.0001)$ and HDLcholesterol $(\mathrm{p}=0.015)$ and no significative influence on the levels of TAG $(p=0,051)$. Comparing the results of total cholesterol (TC) and
HDL-cholesterol (HDL) at the end of treatment (60 d) on the SDG and CDG groups (Table 3), increasing of the values of serum lipids during the treatment were observed, which presented significant differences at the $95 \%$ confidence interval. The rabbits of standard group (SDG) were fed with a standard diet (SD) which was not added of cholesterol and lard, in comparison with the rabbits of cholesterol-diet-group (CDG), which were fed with a cholesterol-diet (CD). The increase of the daily ingesta of cholesterol in CDG caused an increase in lipoproteins in serum since exceeds the necessity required for the organism for synthesis of hormones and biliary salts (Stryer et al., 1996; Champe et al., 1997).

$\underline{\text { Table } 1 \text { Diets composition }}$

\begin{tabular}{lcccc}
\hline Diet & Humidity (\%) & $\begin{array}{c}\text { Ashes } \\
(\mathbf{\%})\end{array}$ & $\begin{array}{c}\text { Proteins } \\
(\mathbf{\%})\end{array}$ & $\begin{array}{c}\text { Lipids } \\
(\mathbf{\%})\end{array}$ \\
\hline Standard diet (SD) & $12.03 \pm 1.49$ & $8.04 \pm 0.23$ & $17.05 \pm 0.17$ & $5.19 \pm 0.44$ \\
Cholesterol diet (CD) & $11.09 \pm 0.08$ & $6.56 \pm 0.05$ & $15.05 \pm 0.67$ & $14.52 \pm 1.37$ \\
Cholesterol-Spirulina diet (CSD) & $11.39 \pm 0.29$ & $7.19 \pm 0.72$ & $15.98 \pm 0.26$ & $11.85 \pm 2.04$ \\
Fat diet (FD) & $10.43 \pm 0.06$ & $8.29 \pm 0.83$ & $15.02 \pm 0.21$ & $15.05 \pm 0.04$ \\
\hline
\end{tabular}

Table 2 Animals weights during the treatments

\begin{tabular}{lccccc}
\hline & SDG & CDG & CSDG & CSDG30 & FDG \\
\hline IW $(\mathrm{g})$ & $3,413.3 \pm 156.7$ & $3,585.8 \pm 204.4$ & $3,566.6 \pm 264.1$ & $3,087.5 \pm 317.5$ & $3,657.5 \pm 292.5$ \\
FW $(\mathrm{g})$ & $3,791.6 \pm 183.3$ & $3,845.0 \pm 377.4$ & $3,693.3 \pm 140.7$ & $3,483.7 \pm 227.7$ & $3,765.0 \pm 265.0$ \\
\hline
\end{tabular}

IW: initial weight; FW: final weight; SDG: standard diet group; CDG: cholesterol diet group; CSDG: cholesterol-spirulina diet group; CSDG30: cholesterol-spirulina diet group-with spirulina after the 30th day; FDG: fat diet group. $\mathrm{N}=3$ in all groups.

Table 3 Total-cholesterol (TC), triacylglycerols (TAG) and HDL-cholesterol in the rabbits in 0, 30 and 60 days of treatment

\begin{tabular}{|c|c|c|c|c|c|c|}
\hline & Time (d) & SDG & CDG & CSDG & CSDG30 & FDG \\
\hline $\begin{array}{c}\mathrm{TC} \\
\left(\mathrm{mg} \cdot \mathrm{dL}^{-1}\right)\end{array}$ & $\begin{array}{c}0 \\
30 \\
60 \\
\end{array}$ & $\begin{array}{l}28 \pm 9^{\mathrm{a}} \\
25 \pm 6^{\mathrm{a}} \\
24 \pm 7^{\mathrm{a}}\end{array}$ & $\begin{array}{c}59 \pm 36^{\mathrm{a}} \\
627 \pm 77^{\mathrm{cd}} \\
1054 \pm 101^{\mathrm{e}}\end{array}$ & $\begin{array}{c}26 \pm 11^{\mathrm{a}} \\
368 \pm 51^{\mathrm{bc}} \\
516 \pm 163^{\mathrm{c}}\end{array}$ & $\begin{array}{c}46 \pm 15^{\mathrm{a}} \\
535 \pm 305^{\mathrm{c}} \\
923 \pm 101^{\mathrm{de}}\end{array}$ & $\begin{array}{c}21 \pm 2^{\mathrm{a}} \\
68 \pm 28^{\mathrm{ab}} \\
43 \pm 34^{\mathrm{a}}\end{array}$ \\
\hline $\begin{array}{c}\text { TAG } \\
\left(\mathrm{mg} \cdot \mathrm{dL}^{-1}\right)\end{array}$ & $\begin{array}{c}0 \\
30 \\
60\end{array}$ & $\begin{array}{l}71 \pm 18^{\mathrm{ab}} \\
64 \pm 47^{\mathrm{ab}} \\
66 \pm 31^{\mathrm{ab}}\end{array}$ & $\begin{array}{l}34 \pm 14^{\mathrm{ab}} \\
59 \pm 17^{\mathrm{ab}} \\
167 \pm 37^{\mathrm{b}}\end{array}$ & $\begin{array}{c}31 \pm 13^{\mathrm{a}} \\
62 \pm 6^{\mathrm{ab}} \\
97 \pm 48^{\mathrm{ab}}\end{array}$ & $\begin{array}{l}59 \pm 21^{\mathrm{ab}} \\
71 \pm 56^{\mathrm{ab}} \\
45 \pm 11^{\mathrm{ab}}\end{array}$ & $\begin{array}{c}47 \pm 10^{\mathrm{ab}} \\
41 \pm 7^{\mathrm{ab}} \\
37 \pm 6^{\mathrm{ab}}\end{array}$ \\
\hline $\begin{array}{c}\text { HDL } \\
\left(\mathrm{mg}^{2} \mathrm{dL}^{-1}\right)\end{array}$ & $\begin{array}{c}0 \\
30 \\
60\end{array}$ & $\begin{array}{l}21 \pm 2^{\mathrm{ab}} \\
15 \pm 5^{\mathrm{a}} \\
15 \pm 2^{\mathrm{a}}\end{array}$ & $\begin{array}{c}38 \pm 22^{\mathrm{abc}} \\
64 \pm 18^{\mathrm{bcd}} \\
73 \pm 31^{\mathrm{cd}}\end{array}$ & $\begin{array}{c}18 \pm 6^{\mathrm{a}} \\
58 \pm 13^{\mathrm{abcd}} \\
91 \pm 16^{\mathrm{d}}\end{array}$ & $\begin{array}{c}29 \pm 10^{\mathrm{abc}} \\
37 \pm 21^{\mathrm{abc}} \\
49 \pm 14^{\mathrm{abcd}}\end{array}$ & $\begin{array}{c}15 \pm 3^{\mathrm{a}} \\
23 \pm 5^{\mathrm{ab}} \\
29 \pm 18^{\mathrm{abc}}\end{array}$ \\
\hline
\end{tabular}

SDG: standard diet group; CDG: cholesterol diet group; CSDG: cholesterol-Spirulina diet group; CSDG30: cholesterol-Spirulina diet group-with Spirulina after the $30^{\text {th }}$ day; FDG: fat diet group.

${ }_{a, b, c, d, e}$ Different superscripts for the same variable mean statistical differences ( $\mathrm{p}<0.05$ by Tukey test).

$\mathrm{N}$ (number of animals in each group) $=3$ in all groups. 
Triacylglycerols levels were higher due to the higher ingesta of lipids, since the cholesteroldiet (CD) contained $14.52 \%$ of lipids, comparing to $5.19 \%$ in the standard diet, but this difference was not significant compared SDG and CDG groups at $60 \mathrm{~d}$ of treatment.

Results of total-cholesterol, triacylglycerols and HDL presented no significant differences to all diets groups in the initial time $(\mathrm{p}=0.133$ to $\mathrm{TC}$, $\mathrm{p}=0.051$ to $\mathrm{TAG}$ and $\mathrm{p}=0.173$ to HDL). These results showed that rabbits were homogeneous with respect to the serum levels of TC and TAG in the initial of treatment and that modifications in these levels in comparison with the final time had occurred due to the differences in treatments. Similar results of TC, TAG and HDL were reported by others authors in rabbits submitted to control diets. Amaral et al. (1995) found levels of $40.25 \pm 22.23$ to $63.75 \pm 10.15$ mg. $\mathrm{dL}^{-1}$ for total-cholesterol and $26 \pm 13.27$ to $42.50 \pm 11.12 \mathrm{mg} . \mathrm{dL}^{-1}$ for HDL-cholesterol. Keaney et al. (1993) found levels of totalcholesterol, HDL and triacylglycerols as $57 \pm 9$, $30 \pm 5$ and $115 \pm 15 \mathrm{mg} \cdot \mathrm{dL}^{-1}$, respectively. These results demonstrated that the variations of rabbits serum lipids found in this work were in according with the biological variability of these animals. Results of TC to SDG and FDG did not present significant differences in all the treatments time $(\mathrm{p}=0.9234)$.

The levels of serum cholesterol decreased from $1054 \pm 101 \mathrm{mg} \cdot \mathrm{dL}^{-1}$ in the rabbits fed with the cholesterol diet $(\mathrm{CD})$ to $516 \pm 163 \mathrm{mg} \cdot \mathrm{dL}^{-1}$ in those fed with the cholesterol-Spirulina diet CSD (significant at $\mathrm{p}<0.0001$ ). The levels of serum high-density lipoprotein (HDL)cholesterol was $91 \pm 16 \mathrm{mg} . \mathrm{dL}^{-1}$ for rabbits fed with the CSD as compared to $73 \pm 31 \mathrm{mg} \cdot \mathrm{dL}^{-1}$ those fed a CD. The means were not different at a confidence level of $95 \%$, according to Table 3, but at a confidence level of $85 \%$ they were significantly different $(\mathrm{p}=0.1533)$. This result was in according with Kay (1991) who observed that Spirulina decreased total plasma cholesterol levels and increased cholesterol associated to high density lipoproteins, suggesting that Spirulina could have a protective effect on the cardiovascular system. Blé-Castillo et al. (2002) observed that when S. maxima was added to diet of mice two weeks prior the onset of fatty liver induction with simvastatin, ethanol and a hypercholesterolemic diet, there was a decrement of liver total lipids (40\%), liver triacylglycerols (50\%) and serum triacylglycerols (50\%) compared to the animals with the same treatment but without the microalgae. In addition, the administration of this alga produced a significant increase (45\%) in serum high-density lipoproteins. According to Hill and McQueen (1997), high-density lipoproteins have long been known to be protective against the development of atherosclerosis. There is an inverse relationship between the HDL concentration and the incidence of coronary heart disease. HDL acts as the transport particle and, as such, occupies a central position in the reverse cholesterol transport system whereby cholesterol synthesized or deposited in peripheral cells is returned to the liver for reuse or re-excretion into the bile.

The elevation in the total cholesterol caused by a cholesterol rich diet was suppressed by the supplementation of $16 \%$ of Spirulina in mice (Kato et al., 1984). In the studies accomplished by Iwata et al. (1987), the addition of 5, 10 and $15 \%$ of Spirulina in mice diets caused significant inhibition in total cholesterol, triacylglycerols, phospholipids and HDLcholesterol levels in the hyperlipidemia caused by fructose. Nakaya et al. (1988) demonstrated the hypocholesterolemic effect of Spirulina when administrated in humans (4.2 g.day ${ }^{-1}$ for 4 weeks). Torres-Durán et al. (1999) observed that $S$. maxima was able to prevent the changes induced by carbon tetrachloride in liver lipids in rats.

The presence of antioxidant compounds like phycocyanin and phenolic compounds, and poly-unsaturated fatty acids in the microalgae Spirulina can be the cause of the properties of Spirulina on the decrease of serum lipids levels. According to Nagaoka et al. (2005), both, $S$. platensis concentrates or phycocyanin, a proteic pigment extracted of Spirulina, caused hypocholesterolemic activity in rats. The in vivo antioxidant capacity of extracts of Spirulina was evaluated by Miranda et al. (1998) in plasma of adult male Wistar rats receiving a daily dose of 5 $\mathrm{mg}$ of extract for 2 and 7 weeks. Plasma antioxidant capacity was measured in brain homogenate incubated for $1 \mathrm{~h}$ at $37^{\circ} \mathrm{C}$. Upon treatment, the antioxidant capacity of plasma was $71 \%$ for the experimental group and $54 \%$ 
for the control group. The authors considered that the amounts of phenolic acids, $\alpha$-tocopherol and $\beta$-carotene presents in Spirulina extracts were responsible by the antioxidant activity. The microalga Spirulina presented poly-unsaturated fatty acids as demonstrated by many authors (Colla et al., 2004; Olguin et al., 2001; Alonso and Maroto, 2000; Quoc et al., 1994; Cohen et al., 1993; Cohen et al., 1987). These compounds have been studied in respect to its therapeutic properties such as its ability to decrease blood cholesterol levels (Ishikawa et al., 1989; Kurushima et al., 1995).

Thus, it could be concluded that supplementing $0.5 \mathrm{~g}$. $\mathrm{d}^{-1}$ of $S$. platensis caused a decrease in the induced hypercholestearolemia in rabbits. The serum levels of cholesterol decreased in the rabbits fed a hypercholesterolemic diet without $S$. platensis in comparison to those fed a hypercholesterolemic diet supplemented with $S$. platensis. In contrast, the serum levels of HDL were higher in the groups fed with Spirulina. These results showed the potential of biomass Spirulina to decrease the serum levels of total cholesterol and to increase the serum levels of HDL-cholesterol, considered as a protective factor against the development of atherosclerosis.

\section{RESUMO}

A microalga Spirulina é cultivada e comercializada no mundo devido a suas características nutricionais (elevada concentração de proteínas, em torno de $65 \%$, vitaminas e sais minerais) e ao seu potencial terapêutico no tratamento de inúmeras doenças, inclusive a hipercolesterolemia. Neste trabalho foi avaliada a inibição da hipercolesterolemia induzida em coelhos por uma dieta adicionada de colesterol (350 mg.d $\left.{ }^{-1}\right)$, pela suplementação de 0,5 g.dia ${ }^{-1}$ de biomassa de Spirulina platensis, sendo avaliados os níveis de colesterol total, triglicerídeos e HDL nos tempos de $0 \mathrm{~d}, 30 \mathrm{~d}$ e $60 \mathrm{~d}$ de tratamento. Os resultados indicaram que a adição de Spirulina platensis na dieta ocasionou decréscimo nos níveis de colesterol total de $1054 \pm 101 \mathrm{mg} . \mathrm{dL}^{-1}$ para $516 \pm 163 \mathrm{mg}$. dL ${ }^{1}(\mathrm{p}<0,0001)$, para os coelhos alimentados com a dieta colesterolêmica em comparação com os que receberam a dieta adicionada de Spirulina platensis. A adição de Spirulina a dieta colesterolêmica não ocasionou decréscimo significativo nos níveis de triglicerídios dos coelhos. Os valores de HDL aumentaram de $73 \pm 31$ mg.dL ${ }^{-1}$ para $91,0 \pm 15,7$ mg.dL ${ }^{-1}$, comparando-se os coelhos alimentados com a dieta colesterolêmica e os alimentados com a dieta adicionada de Spirulina, estatisticamente diferentes a um nível de significância maior que 0,1533 .

\section{REFERENCES}

A.O.A.C. (1995). Official methods of analysis. 16. ed. Association of Official Analytical Chemists. Arlington.

Alonso D. and Maroto F. (2000), Plant as 'chemical factories' for the production of polyunsaturated fatty acids: Biotechnol. Adv. 18, 481-497.

Amaral, D.M.; Moreira, M.; Lobato, M.A.; Abreu, S.M. (1995), Efeito inibidor de substâncias antioxidantes existentes no vinho tinto na aterogênese experimental no coelho. Vittalle, 7,1724.

Becker, E.W.; Jakober, B.; Luft, D.; Schumuling, R.M.; (1986), Clinical and biochemical evaluations of the alga Spirulina with regard of its application in the treatment of obesity: Nutr. Rep. Int. 33, 565574.

Belay, A.; Ota, Y.; Miyakawa, K.; Shimamatsu, H. (1993), Current knowledge on potential health benefits of Spirulina. Journal of Applied Phycology. 5, 235-241.

Bhat, V.B.; Madyastha, M. (2001), Scavenging of Peroxynitrite by phycocyanin and phycocyanobilin from Spirulina platensis: protection against oxidative damage to DNA: Biochemical and Biophysical Research Communications 285, 262266.

Blé-Castillo, J.L.B.; Rodriguez-Hernandez, A.; Miranada-Zamora, R.; Juárez-Oropeza, M.A.; Díaz-Zagoya, J.C. (2002), Arthospira maxima prevents the acute fatty liver induced by the administration of simvastatin, ethanol and a hypercholesterolemic diet to mice. Life Sciences 70, 2665-2673.

Champe, P.C.; Harvey, R.A. (1997), Bioquímica ilustrada, 2. ed., Porto Alegre: Artes Médicas.

Cohen Z.; Reungjitchachawali M.; Angdung W.; Tanticharoen M. (1993), Production and partial purification of gamma-linolenic acid and some pigments from Spirulina platensis: J. Appl. Phycol. 5, 109-115. 
Cohen Z.; Vonshak A.; Richmond A. (1987), Fatty acid composition of Spirulina strains grown under various environmental conditions. Phytochem.: 26 (8), 2255-2258.

Colla, L.M.; Bertolin, T.E.; Costa, J.A.V. (2004), Fatty acids profile of Spirulina platensis grown under different temperatures and nitrogen concentrations: Z.Naturforsch. C, 59, 55-59.

Estrada, J.E.P.; Bescós, P.B.; Villar del Fresno, A.M. (2001), Antioxidant activity of different fractions of Spirulina platensis protean extract: Il Farmaco 56, 497-500.

Gardner, P.T.; White, T.A.C.; McPhail, D.B.; Duthie, G.G. (2000), The relative contributions of vitamin $\mathrm{C}$, carotenoids and phenolics to the antioxidant potential of fruit juices. Food Chemistry, 68, 471474.

Gugliucci, A. (1996), Antioxidant effects of Ilex paraguariensis induction of decreased oxidability of human LDL in vivo. Biochemical and Biophysical Research Communications, 224 (2), 338-344.

Henrikson, R. (1994), Microalga Spirulina Superalimento del futuro. Barcelona: Ediciones S.A. Urano, ISBN 84-7953-047-2.

Hill, S.A.; McQueen, M.J. (1997), Reverse cholesterol transport - a review of the process and its clinical implications. Clinical Biochemistry, 30 (7), 517-525.

Ishikawa T.; Fujiyama Y.; Igarashi C.; Morino M.; Fada N.; Kagami A.; Sakamoto T.; Nagano M.; Nakamura, H. (1989), Clinical features of familial hypercholesterolemia: Atherosclerosis, 75, 95-103.

Iwata, K.; Inayama, T.; Kato, T. (1987), Effects of Spirulina platensis on fructose-induced hyperlipidemia in rats. J. Jap. Soc. Nutr. Food Sci., 40, 463-467.

Kato, T.; Takemoto, K.; Katayama, H.; Kuwabara, Y. (1984), Effects of Spirulina (Spirulina platensis) on dietary hypercholesterolemia in rats. J. Jap. Soc. Nutr. Food Sci., 37, 323-332.

Kay, R.A. (1991), Microalgae as food and supplement: Crit. Rev. Food Sci. Nutr. 30, 555-573.

Keaney, J.F.; Gaziano, M.; Xu, A.; Frei, B.; Celentano, J.C. Shwaery, G.T., Loscalzo, J.; Vita, J.A. (1993), Dietary antioxidants preserve endothelium-dependent vessel relaxation in cholesterol-fed rabbits: Proc. Nat. Acad. Sci 90, 11880-11884.

Kurushima, H.; Hayashi, K.; Shingu, T.; Kuga, Y.; Ohtani, H.; Okura, Y.; Tanaka, K.; Yasunobu, Y.; Nomura, K.; Kajiyama, G. (1995), Opposite effects on cholesterol metabolism and their mechanisms induced by dietary oleic acid and palmitic acid in hamsters. Biochimica et Biophysica Acta, v. 1258, 251-256.
Mahfouz, M.M.; Kawano, H.; Dummerow, F.A. (1997), Effect of cholesterol-rich diets with and without added vitamins $\mathrm{E}$ and $\mathrm{C}$ on the severity of atherosclerosis in rabbits: Am. J. Clin. Nutr. 66, 1240-1249.

Miranda, M.S.; Cintra, R.G.; Barros, S.B.M.; Filho, J.M. (1998), Antioxidant activity of the microalga Spirulina maxima. Brazilian Journal of Medical and Biological Research, 31, 1075-1079.

Nagaoka, S.; Shimizu, K.; Kaneko, H.; Shibayama, F.; Morikawa, K.; Kanamaru, Y.; Otsuka, A.; Hirahashi,T.; Kato, T. (2005). A novel protein Cphycocyanin plays a crucial role in the hypocholesterolemic action of Spirulina platensis concentrate in rats: Journal of Nutrition, 135, 2425 2430.

Nakaya, N.; Honma, Y.; Goto, Y. (1988), Cholesterol lowering effect of Spirulina. Nutr. Rep. Int., 37, 1329-1337.

Olguín E.; Galicia S.; Angulo-Guerrero O.; Hernández E. (2001), The effect of low light flux and nitrogen deficiency on the chemical composition of Spirulina sp. (Arthospira) grown on digested pig waste: Biores. Technol. 77, 19-24.

Perugini, C.; Bagnati, M.; Cau, C.; Bordone, R.; Zoppis, E.; Paffoni, P.; Re, R.; Albano, E.; Bellomo, G. (2000), Distribution of lipid-soluble antioxidants in lipoproteins from healthy subjects. Correlation with plasma antioxidant levels and composition of lipoproteins. Pharmacological Research, 41 (1), 55-65.

Quoc K.; Dubacq J.; Demandre C.; Mazliak P. (1994), Comparative effects of exogenous fatty acid supplementations on the lipids from the cyanobacterium Spirulina platensis: Plant Physiol. Biochem. 32, 501-509.

Ramamoorthy, A.; Premakumari, S. (1996), Effect of suplementation of Spirulina on hypercholesterolemic patients. J. Food Sci. Technol, 33 (2), 124-128.

Reddy, M.C.; Subhashini, J.; Mahipal, S.V.K.; Bhat, V.B.; Reddy, P.S.; Kiranmai, G.; Madyastha, K.M.; Reddanna, P. (2003). C-phycocyanin, a selective cyclooxigenase-2 inhibitor, induces apoptosis in lipopolysaccharide-stimulated RAW 264.7 macrophages. Biochemical and Biophysical Research Communications 304, 385-392.

Renaud, S.; Lorgeril, M. (1992), Wine, alcohol, platelets, and the French paradox for coronary heart disease. The Lancet, 1523-1526.

Schinella, G.R.; Troiani, G.; Dávila, V.; de Buschiazzo, P.M.; Tournier, H.A. (2000), Antioxidant effects of an aqueous extract of Ilex paraguariensis. Biochemical and Biophysical Research Communications, 269 (2), 357-360. 
Silva, E.L.; Meneghetti, J.C.; Coelho, I.J.C.; Abdalla, D.S.P. (1997), Plasma clearance and biodistribution of oxidatively modified ${ }^{99 \mathrm{~m}}$ TC- $\beta$-VLDL in rabbits: Brazilian Journal of Medical and Biological Resesarch 30, 705-717.

Stryer, L. (1996), Bioquímica, 4. ed., Stanford University, Rio de Janeiro: Guanabara Koogan. ISBN 0-7167-3687-X.

Torres-Durán, P.V.; Miranda-Zamora, R.; ParedesCarbajal, M.C.; Masher, D.; Blé-Castillo, J.; Díaz-
Zagoya, J.C.; Juárez-Oropeza, M.A. (1999), Studies on the preventive effect of Spirulina maxima on fatty liver development induced by carbon tetrachloride, in the rat: Journal of Ethnopharmacology 64, 141-147.

Received: August 11, 2005; Revised: February 09, 2006; Accepted: May 17, 2007. 